\title{
The wood pellet business in Russia with the role of North-West Russian regions: present trends and future challenges
}

\author{
Svetlana Proskurina ${ }^{\mathrm{a}}{ }^{*}$, Jussi Heinimö $^{\mathrm{b}}$, Mirja Mikkilä ${ }^{\mathrm{a}} \&$ Esa Vakkilainen ${ }^{\mathrm{a}}$ \\ ${ }^{a}$ Lappeenranta University of Technology, Skinnarilankatu 34, 53850 Lappeenranta, Finland \\ ${ }^{\mathrm{b}}$ Innovation and Technology Center Miktech Oy, Sammonkatu 12, 50130 Mikkeli, Finland
}

${ }^{*}$ Corresponding author. Tel.: +358 466322953 .

E-mail addresses: svetlana.proskurina@lut.fi, proskurina.s@mail.ru (S. Proskurina).

Postal address: Finland, 53850 Lappeenranta, Skinnarilankatu 34.

\section{ABSTRACT}

The Russian wood pellet business has expanded rapidly in the last decade. The first Russian pellet production plant was built in 2003 and within ten years, Russia has become an important exporter of pellets, mainly to the Nordic and Baltic area. The aim of this paper is to present an overview of the current status of the Russian pellet market with particular emphasis on pellet exports. In addition to reviewing the state of the pellet market in Russia, the paper addresses challenges facing the Russian wood pellet business, both domestically and in key export markets. The paper is based on a review of published scientific literature, trade magazines, the latest Russian official documents and reports, as well as interviews with experts and the materials of IEA Bioenergy Task 40. Attempts have been made to reconcile the varying and conflicting data given in different Russian documentation sources, thus permitting a more accurate representation of the Russian pellet business, an important player in the global pellet trade. Despite its importance, there is limited work available on the Russian pellet industry and this paper thus contributes to greater understanding of the Russian pellet business. Based on an analysis of the market situation, challenges and opportunities are presented for future scenarios of Russian pellet exports. The study further demonstrates the important role that Russia plays in the global pellet market. This paper finds that although the Russian pellet business developed very rapidly during 2004-2009, the industry now faces considerable challenges. Due to an oligopolistic market structure, inadequate infrastructure and lack of foreign investments, it is expected that, despite its obvious potential, the Russian wood pellet industry may not develop significantly in the near future and exports to Europe could even decline.

Keywords:

Wood pellets

Russia

Export

Import

Bio-economy

Challenges 


\section{Abbreviation}

$\mathrm{CO}_{2}$ carbon dioxide

CPM California Pellet Mill

EPC European Pellet Council

EU European Union

EU-27 Austria, Belgium, Bulgaria, Croatia, Cyprus, Czech Republic, Denmark, Finland, France, Germany, Greece, Hungary, Ireland, Italy, Latvia, Lithuania, Luxembourg, Malta, the Netherlands, Poland, Portugal, Romania, Slovakia, Slovenia, Spain, Sweden, United Kingdom

FSC Forest Stewardship Council

GHG greenhouse gas

IEA International Energy Agency

MDF medium density fibreboard

NRAP National Renewable Action Plan

UK United Kingdom

\section{Definitions}

\section{Biomass}

Refers to the biodegradable fraction of products, waste and residues from agricultural (including vegetal and animal substances), forestry and related industries, as well as the biodegradable fraction of industrial and municipal waste.

\section{Industrial pellet}

Refers to pellets that are produced for industrial purposes such as heat and power production.

\section{Wood pellet}

Refers to pellets that are produced from wood. 


\section{Introduction}

Pellet production plays a crucial role in bioenergy development. Biomass is a variable and complex material with considerable challenges when used directly for energy production. Its conversion into densified products will promote the use of bioenergy as a commodity that can be traded worldwide. Moreover, refined solid biomass exhibits high flow-ability in various handling systems and processes, and its energy density is several times higher than untreated raw biomass. Therefore, a future bio-based economy will benefit from the widespread adoption of densified solid biofuels, such as pellets, that can be efficiently handled, stored, and transported [1].

For heat and power production pellet fuel is essential, with the most common and most widely used types of pellets being wood pellets made from side streams from sawmilling and wood products manufacture [2]. For tens of thousands of years, humankind has been burning wood to generate heat and energy, and wood pellets are a modern form of wood heating that arguably has greater potential to cut carbon dioxide $\left(\mathrm{CO}_{2}\right)$ emissions than any other source of renewable energy currently available [3]. Wood pellets, unlike raw wood, contain very low levels of moisture and produce little ash, so virtually all of the material is burned and converted to heat [4].

In view of its promise, the importance of wood pellets in the energy mix is increasing, and a large number of countries are building new wood pellet-fired heating plants and thermal power stations $[5,6]$.

Trømborg et al. [7] present the typical production steps of pellet production (Fig. 1) in small and large scale pellet plants with 20000 tons per year and 120000 tons per year of production capacity respectively. The process starts with storage facilities for the feedstock and forwarding of the wet feedstock to a dryer as reduction down to $10 \%$ water content is required. Relative temperature, air humidity, particle size of the feedstock and drying technology are factors that impact on the exact energy demand for drying. After drying, material other than sawdust is chipped and/or ground to achieve the required particle size for pellet production. After that the particles are pelletized. The pellets are then forwarded to a counter stream cooler and from there finally to a storage facility [7].

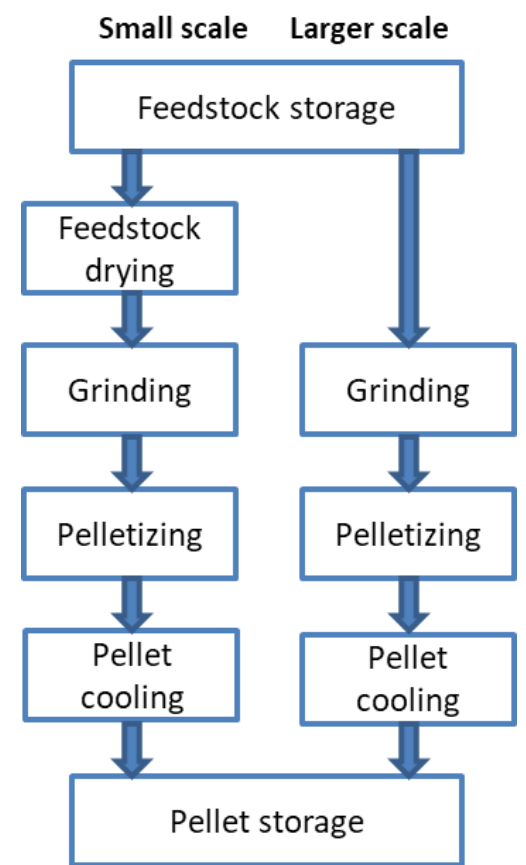

Fig. 1. Production steps for pellet production in small and large scale pellet plants [7]. 
Depending on the feedstock, pellets could be wood pellets or grass pellets, which are made by pelletizing of wood and grasses respectively. The most commonly used raw material for producing pellets is wood in the form of sawdust and shavings [1].

Trømborg et al. [7] state that future pellet production will, to a large extent, be based on wet feedstock such as wood chips, round wood and wet sawdust. These feedstocks are also in demand by other wood-based industries like the traditional forest industries (pulp and paper, particle- and fiber-board) as well as for bioenergy production from wood chips and firewood.

Wood pellets can be used in pellet stoves, boilers and furnaces in power and combined heat and power (CHP) plants as well as in private houses. Depending on the application, pellets can be in the form of either residential fuel or industrial pellets.

In many countries, internal biomass potential and wood pellet production are insufficient to meet the energy needs of the country, and a key aspect of the wood pellet business has thus become the international trade in pellets [8]. In 2006, the production of wood pellets was estimated at between 6 and 7 million tons worldwide [9]. In 2012, global wood pellet production had roughly tripled and reached 18.5 million tons [10], while the global capacity for wood pellets was estimated to be 28 million tons in 2010 [6,11], which means that the industry has significant potential for development.

Due to past and expected future EU demand and industrial developments in the sector, such as large-scale use of wood pellets in co- and mono-firing installations, wood pellets have become the largest single commodity stream in the wood manufacturing industry and an important item in international trade. In addition, wood pellets are a key diversification strategy of many forestry companies and other traditional forest sector players, such as mechanical wood product companies [12-15].

In EU-27, wood pellet consumption was 9 million tons in 2009. This number grew to 11.4 million tons in 2010 and increased to 13 million tons in 2012 [16]. Global wood pellet consumption forecasts to 2020 vary greatly. Depending on the source, market growth for wood pellets is projected to grow by $200 \%-300 \%$ from 2012 to 2020 , rising from 16 million to 40 50 million tons [17-19]. Lamers et al. [12] report a projected increase in wood pellet imports in EU-27 by 2020 with expected volume in the range of 15-20 million tons.

Russian pellets have an important share of global markets. In 2012, Russia was the world's fifth largest exporter of wood pellets after USA, Canada, Latvia, and Germany [20]. During the last ten years, more than 200 pellet production plants have been built in Russia-from small facilities with an annual capacity of one hundred tons to large plants with a million tons of pellet production per year [21,22]. The North-West regions of Russia benefit from the availability of plentiful forest resources and the relative proximity to the main European markets and ports.

In Russia, wood pellet producers typically use dry residues from sawn wood production as a raw material. Generally, these dry residues have historically been the main feedstock worldwide due to low prices, no requirements for thermal drying of the feedstock, a relatively homogenous composition as well as a low ash content [7].

There has been very little public discussion about trade restrictions and expected developments in the Russian wood pellet market, and limited work has been presented that focuses specifically on the Russian pellet industry. Aleksandrova [23] presented an analysis of the wood pellet market in Russia, in which the characteristics of the Russian wood pellet market are described and sales strategies for Russian producers suggested. The authors do not, however, consider the 
main suppliers by region, nor discuss the European market and market restrictions in detail. Currently, the wood pellet industry has a heightened need for further research on this question.

The aim of this paper is to determine wood pellet market dynamics in Russia, to identify the main pellet suppliers by region and volume, to examine domestic demand for wood pellets, and to discuss the challenges facing the Russian wood pellet industry. The paper also provides updated information about Russian wood pellet industry development and presents volumes of exports and production with a focus on European markets. The paper focuses primarily on the North-West regions of Russia and exports to Europe.

Earlier studies have shown that the EU-27 has become heavily import-dependent in the industrial pellet market $[24,25]$. The increase in demand in the EU is stimulating large Russian investments in new pellet plants and a rapidly increasing production capacity [5]. This paper describes the market status and production of industrial wood pellets, which dominate the Russian pellet market.

The wood pellet market structure in several countries is different. Trømborg et al. [7] present the market structures of wood pellet markets in a number of European countries and the USA. Analysis of the market characteristics of Russian's main 98 wood pellet plants and their distribution by capacities is presented by Orlov [26]. Based on these studies, it is possible to make a comparison of the Russian market for wood pellets with that of several other countries. Table 1 gives a general overview of the wood pellet market structure in several countries. Selkimaki et al. [27], for example, suggest that Sweden has 94 pellet plants/producers in 2007. More discussion about the pellet markets in the listed countries are presented in other section of the paper.

Table 1 Characteristics of analyzed pellet markets in 2009 [7,26].

\begin{tabular}{|l|c|c|c|c|c|c|c|}
\hline Country & $\begin{array}{c}\text { Pellet } \\
\text { production, } \mathrm{t}\end{array}$ & $\begin{array}{c}\text { Domestic pellet } \\
\text { consumption, } \mathrm{t}\end{array}$ & $\begin{array}{c}\text { Market price, } € \mathrm{t} / 1 \\
\text { (bulk) excl VAT }\end{array}$ & $\begin{array}{c}\text { Number } \\
\text { of plants } \\
0-5000 \mathrm{t}\end{array}$ & $\begin{array}{c}\text { Number of } \\
\text { plants }\end{array}$ & $\begin{array}{c}\text { Number of } \\
\text { plants }\end{array}$ & $\begin{array}{c}\text { Number of } \\
\text { plants above } \\
1000\end{array}$ \\
\hline Finland & 290000 & 188 & 170 & 7 & 9 & 11 & 0 \\
\hline Germany & 1600000 & 1100000 & 193 & 5 & 10 & 15 & 11 \\
\hline Norway & 46500 & 43 & 152 & 5 & 3 & 0 & 0 \\
\hline Sweden & 1576000 & 1958000 & 166 & 6 & 8 & 16 & 6 \\
\hline US & 4400000 & 4150000 & 161 & 4 & 25 & 48 & 8 \\
\hline Russia* & 1000000 & 150000 & 120 & 32 & 46 & 18 & 2 \\
\hline
\end{tabular}

*data for 2011

The rest of this paper is structured in the following way. Section 2 describes the development of wood pellet production in Russia. Section 3 begins by detailing the theoretical dimensions of the research and examines how the Russian wood pellet market is organized in the North-West regions. Section 4 studies the current state and expected development of Russian wood pellet exports to EU markets, describing the main consumers. Section 5 assesses challenges facing the Russian pellet industry and considers the future of Russian pellet industry, and Section 6 concludes the paper. 


\section{Development of wood pellet production in Russia}

Pellet production in Russia started at the beginning of 2001, with the first plants being built in the Leningrad area. The first companies involved in pellet production were "Rospolitehles" and "Biotope". Most of the early companies ceased operations quite quickly [5]. The production facilities used in these early production plants had poor efficiency and operated with secondhand machinery producing low quality pellets. The first factories used traditional feed mill equipment, which had been installed at hundreds of Soviet farms during the 1970s-80s. The equipment (pellet press models were OGM-0,8 and OGM-1,5) was designed based on an old type of California Pellet Mill (CPM). It was produced at a range of former Soviet machinebuilding factories in Radviliškis (Lithuania), Rostov (Russia), Kurgan (Russia), and Kyiv (Ukraine). Initially, most pellet factories installed second-hand pellet machinery, as well as second-hand hammer-mills and dryers (where necessary), originally manufactured during Soviet times. Later, machine-builders offered similar machines to the emerging pelleting industry [28]. Achieving good quality products using such non-core equipment was impossible, thus the pellet price was low, reflecting the poor quality of the product. The cost of establishing this type of small-scale production was relatively small: ten or twenty million rubles (approximately 200 000-400 000 euros). Well-established links with local logging companies meant there was no issue with access to raw material [21]. Indeed, pellet production helped in resolving problems of waste disposal from wood processing. First pellet plants in the Leningrad region are presented in Figure 2.

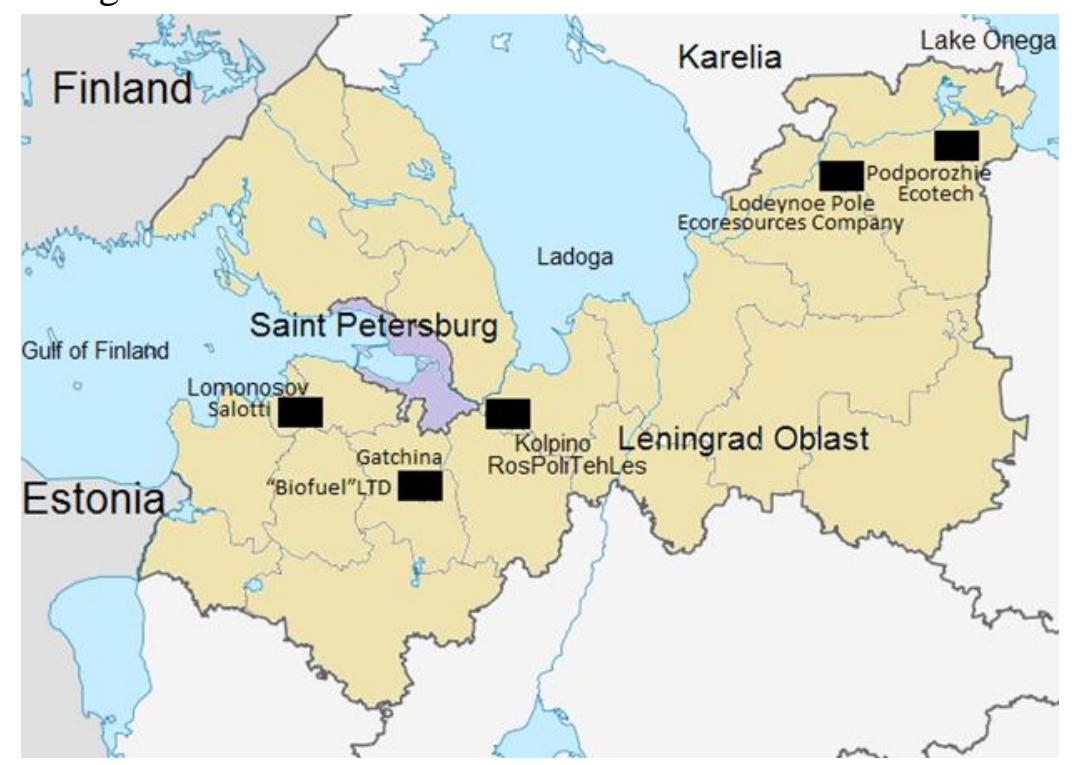

Fig. 2. First pellet plants in the Leningrad region, 2004, from [28].

At the beginning of the $21^{\text {st }}$ century, all pellets produced in Russia were exported. Several small producers would collect pellets and deliver them by single ships to Europe. The quality of the pellets was inferior and the image of Russian pellets in Europe was poor [28]. Later, owners of the pellet plants closed many of these early facilities and opened new plants, in which new modern machinery was installed and used. The number of pellet plants increased significantly from 2001 to 2009 (see Fig. 3). 


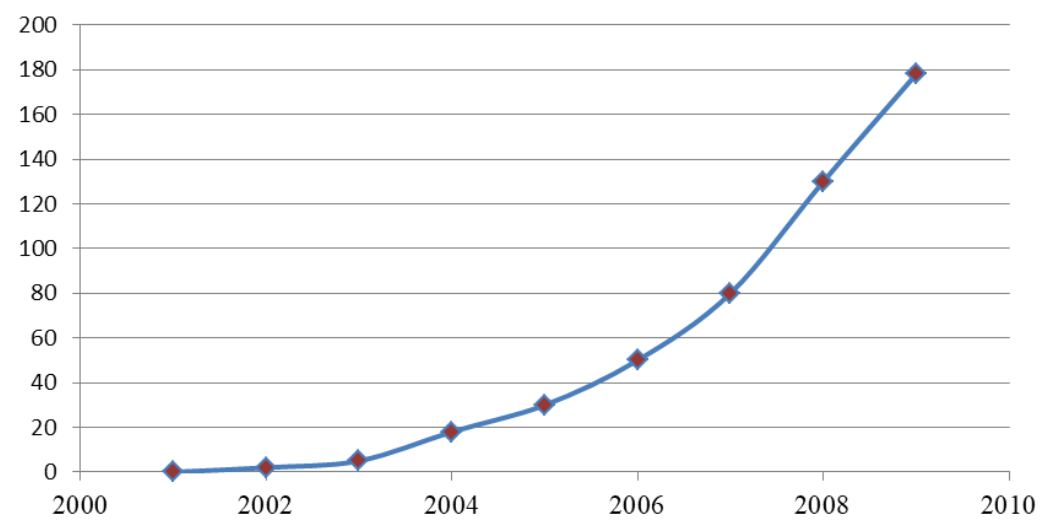

Fig. 3. Number of pellet plants in Russia during 2001-2009 [28].

However, when comparing of Russian wood pellet plants in 2009 (Fig. 3) and in 2011 (Table 1), we note that even if all plants might not have been taken into consideration in the study by Orlov [26] (Table 1), after 2009 the number of Russian wood pellet plants decreased. In addition, trade sources report that the number of wood pellet processing facilities companies in Russia was 150 in 2010, while in 2013 this number decreased to 60 with a high degree of consolidation [21]. Until recently, sawdust, wood chips, and bark were often burned in on-site boilers, or at best, were manufactured to wood boards (e.g. medium density fibreboard (MDF), particleboard, etc.). However, the cost of construction of new wood board production lines, coupled with the highly competitive market, discouraged investment. Pellet production manufacture is relatively cheap, and the price of market entry and product distribution is low. As a result, almost all current largescale pellet production is ancillary activity designed to optimize the cost of recycling of wood [29]. This is one of the main reasons why pellets production in Russia became attractive [8].

\section{Current status}

\subsection{Main producers by Russian region}

Pellet production distribution by region is uneven (see Fig. 4). Currently, the majority of pellet production plants (approximately 60\%) are concentrated in the North-West regions of Russia. About $30 \%$ of Russian pellet production is located in the Central regions and about $10 \%$ of pellets are produced in other Russian regions [28].
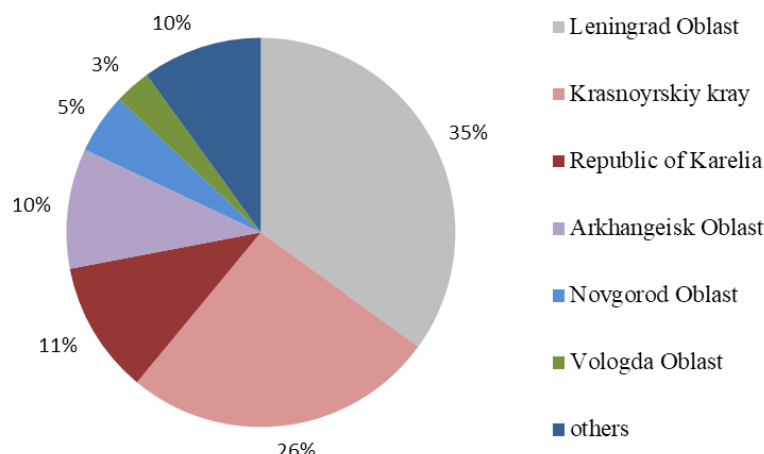

Fig. 4. Regional distribution of pellet production in \%, 2011 [29].

The main player is "Vyborgskaya Cellulose" (recently renamed "Vyborg Timber Corporation", "VTC"), which has the biggest pellet manufacture capacity in the world [30]. The pellet plant is 
situated on the site of the pulp and paper mill "Vyborgskaya Cellulose" in Sovetsky in the Leningrad region, near the Finnish border [29]. However, "VTC" has low working efficiency and currently never operates at full capacity [31]. The production leader is followed by "Sawmill 25", "Setonovo", and "Talion Terra". "Swedwood Tikhvin" was the smallest of the major producers in 2011, with annual production of approximately 5000 tons. Other pellet producers work on an even smaller scale, and some mills export only a few tons of fuel pellets per year [29,22] (see Table 2).

"DOK Yenisei" and "Novoyeniseisk LHK" are big producers of wood pellet with production with 66000 tons and 38000 tons respectively in 2011. However these companies are located in Krasnoyrsk Krai in the Central region of Russia, and thus are not taken into consideration in this study.

Table 2 Main producers of wood pellets in North-West Russia and their exports [22,24,32,33].

\begin{tabular}{|l|l|l|l|l|l|l|}
\hline \multicolumn{1}{|c|}{ Company } & \multicolumn{1}{|c|}{ Region } & $\begin{array}{c}\text { The group or } \\
\text { ultimate } \\
\text { ownership }\end{array}$ & $\begin{array}{c}\text { Start of } \\
\text { operation }\end{array}$ & $\begin{array}{c}\text { Capacity } \\
\text { in } 2011 \\
\text { (ktons) }\end{array}$ & $\begin{array}{c}\text { Production } \\
\text { in } 2011 \\
\text { (ktons) }\end{array}$ & $\begin{array}{c}\text { Export first } \\
10 \text { month of } \\
2013 \text { (ktons) }\end{array}$ \\
\hline OOO "VTC" & Leningrad Oblast & n/a & 2011 & 1000 & 220 & 263 \\
\hline ZAO "Sawmill 25" & Arkhangelsk Oblast & The group "Titan" & 2009 & 110 & 105 & 74 \\
\hline OOO "Swedwood Tikhvin" & Leningrad Oblast & IKEA & 2011 & 75 & less 5* & 38 \\
\hline OOO "Setnovo" & Novgorod Oblast & Stora Enso & 2007 & $70^{*}$ & 60 & 39 \\
\hline ZAO "North-West Holding" & Leningrad Oblast & n/a & 2009 & n/a & n/a & 34.5 \\
\hline "Taleon Terra" & Tver Oblast & STOD & 2009 & 60 & 50 & 35.4 \\
\hline "Setles" & The Republic of Karelia & Stora Enso & 2009 & 30 & $25^{*}$ & n/a \\
\hline "Biogran" & The Republic of Karelia & $\begin{array}{l}\text { Russian Forest } \\
\text { Alliance }\end{array}$ & 2008 & 20 & 25 & 41 \\
\hline
\end{tabular}

* preliminary data

In recent years, several new production plants have come on stream: For example, "Swedwood Tikhvin", with a capacity of 75000 tons of pellets, launched production in 2011. Other big projects are being planned, both in the Leningrad region and in other regions. The new company "Russian Wood Pellets" ("RWP") plans to construct several pellet mills with a total capacity of 3 million tons of pellets per year [29]. The scenario of moderate forest sector development of the Arkhangelsk region [34,35] mentions increasing pellet production to 0.28 million tons by 2020 , and up to 0.42 million tons by 2030. One of the new pellet plants being built in the Arkhangelsk region is owned by the Russian company "Bionet", which has started the construction of a plant for pellet production from timber waste on the site of a former hydrolysis plant in the town of Onega, Arkhangelsk region. This project is being undertaken with the strategic partnership of OAO "Gazprombank", which became an investor and financial backer in 2012 [8,36].

According to Russian Federal Statistics Service [37], Russia produced 0.46 million tons of wood pellets and about 0.6 million tons in 2011 and 2013 respectively. Most analysts, however, believe that actual wood pellet production in 2011 was at least three to four times higher than the official figure [29,38]. Production level was more than 1 million tons in 2009 [39], in 2011 [40] and in 2013 [33]. The Russian journal "LesOnline" [41], informs that the production of wood pellets in Russia was 0.81 million tons in 2013.

There is conflicting data on levels of Russian pellet exports. Russia exported 0.38 and 0.5 million tons of pellets to EU countries in 2009 and 2010 respectively [37,42]. According to other research, the exports were approximately 0.5—0.6 million tons in 2009-2010 [5]. In 2011, 2012, 
2013, exports of wood pellets totaled approximately 0.9 [40], 0.74 and 0.72 million tons respectively [43] (see Table 3).

Data given in different Russian documents varies considerably and is often contradictory. Table 3 presents as compilation from these sources the estimated overview of Russian production and export.

Table 3 Comparison of Russian production and export (1 ktons) [21,40,41,43].

\begin{tabular}{|l|c|c|c|c|c|}
\hline & 2009 & 2010 & 2011 & 2012 & 2013 \\
\hline Production & $\sim 600$ & $\sim 800$ & $\sim 850$ & $\sim 880$ & $\sim 810$ \\
\hline Export & $380-550$ & $500-600$ & $\sim 700$ & $\sim 740$ & $\sim 720$ \\
\hline
\end{tabular}

In 2013, pellet production decreased, in contrast to 2011 and 2012. This reduction was due to a lack of raw material for pellet production and the temporary suspension of production at "VTC", which stopped production at the beginning of 2013 and restarted production only in July 2013 $[41,44]$. Despite the cessation in production, "VTC" was responsible for a big share of exports to the EU (see Table 2). This can be explained by the fact that the company bought pellets from other producers and supplied it as its own product [45]. At the same time, "Sawmill 25" increased production of pellets by $5.4 \%$ in 2013 [44].

\subsection{Domestic demand for wood pellets}

Russian interest in pellet production was initiated by western European utilities, which were looking for new pellet supplies. When the first pellet production plants were set up, the term "pellets" was unknown in Russia, and the domestic market started to develop only several years after the commissioning of the first plants [39].

Domestic consumption data vary depending on the source. Russia used around 5\%-15\% of pellets on domestic markets in 2007 and around 10\%-20\% in 2008-2009. At the beginning of 2009, approximately 15\%-30\% of Russian-produced pellets were used inside Russia [46]. Other expert estimation gives about $10 \%$ local use or even less, if wood pellets suitable for supply to foreign consumers are taken into account [45]. The lower grade pellets mainly are used on domestic markets. Orlov [26] presents domestic consumption of 150000 tons of pellets, which is $15 \%$ of the total production in 2011 (see Table 1). In the most favorable forecasts, the consumption of wood pellets in Russia by 2015 will be 350000 tons [47]. This figure seems impossible based on the current situation of the Russian pellet industry.

The Russian government has identified the development of Russia's forestry sector as a strategic necessity, and production within this sector is expected to increase substantially by 2020 [39]. In 2013, government documents also mentioned support of a pilot project concerning replacement of coal by pellets in a CHP plant in Kirov Oblast. It is projected that the CHP will use 100000 tons of pellets per year [48].

\subsection{Standards}

Standards provide customers with guarantees about minimum product quality and help to ensure product functionality and compatibility, which facilitate interoperability and support consumer safety and public health certification [38]. End-consumers are mainly interested in the energy content of the pellets, the emissions generated by pellet combustion and the effects of the use of pellets in boilers and stoves [47]. 
García-Maraver et al. [47] presented a comparison of different standards currently existing in European countries such as Austria, Sweden, Germany, Italy and France. The pellet quality parameters that appear most frequently in standards and recommendations of different countries are pellet size, moisture content, heating value, and ash content. Pellet size (diameter, length and/or length/diameter ratio) is the only parameter that is included in all the norms.

Two popular pellet quality certification standards accepted by regional pellet producers and pellet consumers are the DINplus pellet certification and ENplus pellet certification (Table 4). Pellets certificated by DIN and EN standard are commonly accepted as "premium" [49]. ENplus includes quality classes, which are A1 and A2. Class A1 refers to the premium quality and is used in private household boilers or stoves. A1 pellets produce the least amount of ash and fulfill the highest requirements. Class A2 is used in larger installations and produces more ash [50]. DINplus is a German standard for pellets and briquettes. In fact, today DINplus is the most important quality certification for wood pellets worldwide [38].

Table 4 Comparison of parameters for DIN and EN-plus pellets [49].

\begin{tabular}{|l|c|c|c|c|}
\hline \multicolumn{1}{|c|}{ Parameter } & Unit & DINplus & ENplus-A1 & ENplus-A2 \\
\hline Diameter & $\mathrm{mm}$ & $4 \sim 10$ & $6 \sim 8$ & $6 \sim 8$ \\
\hline Length & $/$ & $<5 \times \mathrm{D}$ & $3.15 \leq \mathrm{L} \leq 40$ & $3.15 \leq \mathrm{L} \leq 40$ \\
\hline Bulk density & $\mathrm{kg} / \mathrm{dm}^{3}$ & $>1.12$ & - & - \\
\cline { 2 - 5 } & $\mathrm{kg} / \mathrm{m}^{3}$ & - & $\geq 600$ & $\geq 600$ \\
\hline Heat value & $\mathrm{MJ} / \mathrm{kg}$ & $>18$ & $\geq 16.5$ & $\geq 16.3$ \\
\hline Moisture content & $\%$ & 10 & $\leq 10$ & $\leq 10$ \\
\hline Abrasion & $\%$ & $<2.3$ & no & no \\
\hline Fine material $(<3.15 \mathrm{~mm})$ & $\mathrm{no}$ & no & $\leq 1$ & $\leq 1$ \\
\hline Ash content & $\%$ & $<0.5$ & $\leq 0.7$ & $\leq 1.5$ \\
\hline Chlorine content & $\%$ & $<0.02$ & $\leq 0.02$ & $\leq 0.03$ \\
\hline Sulfur content & $\%$ & $<0.04$ & $\leq 0.05$ & $\leq 0.05$ \\
\hline Nitrogen content & $\%$ & $<0.3$ & $\leq 0.03$ & $\leq 0.05$ \\
\hline Heavy metals & $\%$ & regulated & regulated & regulated \\
\hline
\end{tabular}

European standards for solid biomass (CEN/TC 335) were introduced in 2011. The CEN/TC 335 standard was developed only for non-industrial biomass use. The European Pellet Council (EPC) developed ENplus, a traceability and certification scheme, which implements ENplus standard [38]. The standard regulates heating value, utilized materials, and the percentage of ash content of certain chemical elements in standard compliant pellets [8,51].

Currently, there is no national standard for wood pellets quality in Russia. Russian producers are mainly oriented to the DINplus. Trade sources report that the EU currently does not require certification for Russian wood pellets as long as the product is manufactured in compliance with DINplus [39].

In Russia, there is no any certification of wood pellets sustainability such as Forest Stewardship Council (FSC), which is recognized in the USA and has solid reputations in Europe [52]. Unreliable data about the quality of the products and a lack of any production certification decrease Russian pellet competitiveness on the world pellets markets. 


\section{Exports and main EU consumers}

\subsection{Annual production and exports}

The Russian pellet industry is heavily reliant on exports, mainly to the EU and South Korea. As with the data for domestic consumption and production, also the export data varies depending on the source (Section 3.1, Table 3).

In 2012, "VTC" exported 0.5 million tons of wood pellets to Europe [21], which is almost two times less than the production capacity. Despite attempts to develop a domestic market for biofuels in the Archangelsk region, "Sawmill 25" focused mainly on exports to European markets [53,54] (see Table 2). Reflecting the decreased production of wood pellets in "VTC" (Section 3.1) and intensive development of wood pellet production in the Archangelsk region (Section 3.1, Section 5.2), we can see a trend of increased export volume of ZAO "Sawmill 25" and decreased export volume of "VTC".

\subsection{EU consumption of wood pellets}

Although EU-27 was the largest global producer of wood pellets with 10.5 million tons in 2012 [55], EU countries import significant volumes of fuel pellets to meet their renewable energy targets [56-59]. Since 2008, European demand for pellets has significantly outpaced domestic production [39]. Imports from non-member countries were 4.5 million tons in 2012, which meant an overall increase of $158 \%$ over 2009 [55]. Russia's share of the EU's total 2010 imports was $20 \%$ [39].

Northern and central Europe is a major market for pellets. European demand is mostly met by North America as well as internal supply and deliveries from Russia [20]. In the Netherlands, Belgium, and the UK, pellet consumption is dominated by large-scale power plants, and pellets are mainly sourced from the USA and Canada. Russia is the third largest exporter of wood pellets to the EU area after USA and Canada [39,56] (Table 5).

Table 5 Main suppliers of wood pellets to the EU (1 ktons) [39].

\begin{tabular}{|l|c|c|c|c|}
\hline & 2009 & 2010 & 2011 & 2012 \\
\hline US & 535 & 763 & 1029 & 1764 \\
\hline Canada & 520 & 983 & 1174 & 1346 \\
\hline Russia & 379 & 369 & 475 & 637 \\
\hline Ukraine & 30 & 57 & 149 & 217 \\
\hline Croatia & 72 & 95 & 115 & 136 \\
\hline Belarus & 75 & 90 & 100 & 112 \\
\hline Other & 160 & 226 & 226 & 276 \\
\hline Total & 1771 & 2583 & 3268 & 4488 \\
\hline
\end{tabular}

The consumption of Russian pellets is greatest in northern Europe, mainly in Scandinavian countries such as Denmark and Sweden, where pellets are used not only by power plants but also by households and district heating plants [27,57,60,61]. Despite the significant domestic production in these countries, they are dependent on imports, predominantly from the Baltic region and Russia [39].

More than 0.2 million tons of wood pellets were exported from Russia to Denmark during the first 6 months of 2012. Sweden imported under 0.2 million tons of wood pellets in the same period [62]. For comparison, in 2009, the trade volume of Russian wood pellets to Denmark was 87000 tons and to Sweden 163000 tons [58]. According to the latest estimation, Denmark 
continued to be in the first position in July-November 2013. The main two leaders, Denmark and Sweden, are followed by Finland, Italy, and Germany (see Fig. 5). Other consumers of Russian pellets were Latvia with 5478 tons, Estonia with 4253 tons, Lithuania with 2060 tons, Hungary with 1643 tons, and Belgium and Slovenia with 1232 tons and 1180 tons, respectively, as well as Austria with 1020 tons. Several other EU countries consume smaller volumes, less than 1000 tons of Russian pellets per year [48].

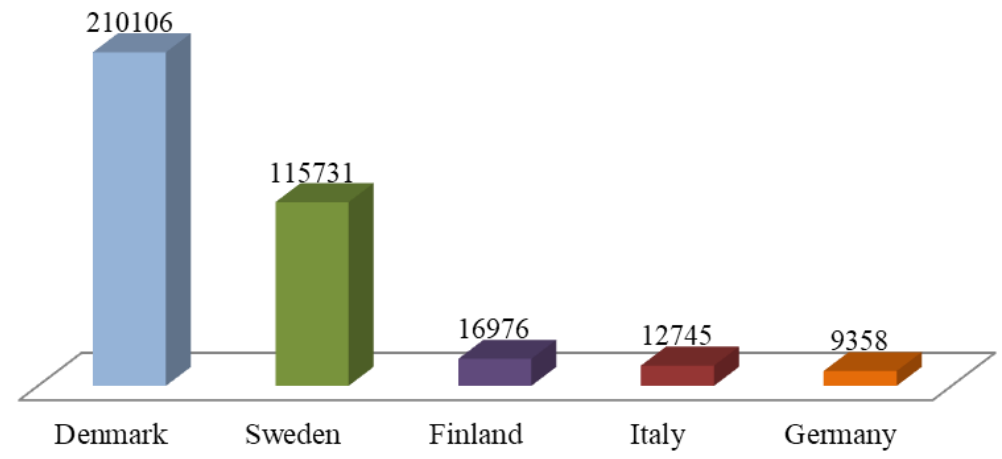

Fig. 5. Top 5 main EU countries/consumers of Russian pellets in July-November 2013 (tons) [48].

The two main buyers of Russian pellets are S. Syr. Pederson AS, -a Norwegian trader, and Lantmännen Agroenergi, -a Swedish manufacturing and trading company [5]. Both enterprises have worked in Russia for a long time. Many European energy companies are also involved in the Russian pellet trade. "Electrabel" (Belgium), "Dong Energy" (Denmark), and "Fortum" (Sweden) use Russian pellets, which they buy through major trading companies such as "Teknoinvest Limited". "Biowatti" from Finland imported some pellets in 2009 but ceased to import them into Finland in 2010. Several other smaller companies, such as "Land-Trading" (Finland), and "Biomass Partners" (Denmark), buy pellets from Russia [29].

\subsubsection{Denmark}

Denmark had the highest level of wood pellet imports among the EU-27 member states in 2012 [55] with 2.03 million tons [20]. Danish pellet production is very small compared to consumption, mainly due to the lack of raw materials. Since 2000, the consumption of wood pellets in Denmark has increased significantly, reaching approximately 0.92 million tons in 2005 [5] and 2.0 million tons in 2012 [55]. This increase is almost exclusively due to the establishment of Avedøre Unit 2, which consumes large amounts of wood pellets (0.25 million tons per year) [5].

\subsubsection{Sweden}

Imports play an important role in meeting wood pellet demand in Sweden [27,60]. Country is an important consumer of Russian pellets, although the country was the second largest producer of pellets in the EU in 2010, with 1.4 million tons of wood pellets (17.5\% of the EU-27) [55]. Prior to, Canada was the main single supplier country. Pellet imports for 2008 were from the following countries, in order of import quantity: Latvia, Russia, Finland, Estonia, Canada, Poland, and Portugal. The top position of Latvia can be explained by the fact that a substantial share of the Latvian pellet industry is owned and managed by Swedish companies [63]. In 2012, Russia was the largest supplier followed by Estonia and Denmark [20]. 


\subsubsection{Finland}

Finland has a long land border with Russia, and the import of wood pellets to Finland was reported for the first time in 2008. Imported pellets came mainly from Russia and the Baltic states $[27,62,64,65]$. In 2004-2009, domestic consumption of wood pellets more than trebled [66]. In 2008, pellet production was 373000 tons. In 2009, pellet production decreased by $20 \%$ to 299000 tons, mainly due to poor availability of raw materials like sawdust from sawmills [67]. The country has a target of 7.2 PJ (0.42 million tons) for the use of pellets by 2020 , according the National Renewable Action Plan (NRAP) [68,69]. The imports of raw material from Russia such as round wood, chips, etc. is higher than wood pellets [65,70]. Despite the large consumption of wood pellets, Finland does not import a lot of Russian pellets, unlike Denmark and Sweden, due to its own production. However, according to Statistics Finland [71], the country imported 60100 tons of wood pellets in 2013, which is more than double the figure for the previous year. The main exporters were Russia and Latvia with 37900 tons and 11100 tons of wood pellets respectively.

\subsubsection{Germany and Austria}

In Austria and Germany, pellet markets are very well established, and the production and consumption of pellets is one of the highest in Europe. These countries have in common that they produce enough pellets for the domestic market and also for exportation [57].

In Austria, companies in the pellet sector are well networked and the industry as a whole focuses on expanding and developing the market. Austria is the only country that has a national standard to ensure the quality of pellets during transportation (ÖNORM M7136) as well as quality criteria for wood pellet storage in households (ÖNORM M7137) [57,72].

In Germany, large parts of the pellet production are located in southern and southwestern Germany. There are high concentrations of wood-related industries in these parts of the country therefore adequate raw material supply. Overall production and the number of plants have increased sufficiently to meet domestic demand for pellets and also to enable significant export volume [57]. From 2004 until 2010 the consumption and production increased constantly. In 2010, German wood pellet production was 1.75 million tons, of which $30 \%$ was exported [69].

Austria and Germany are major exporters of wood pellets [57]; thus the share of Russian wood pellets on Austrian and German markets is not big. Germany consumes a small volume of Russian pellets (as seen in Fig. 5). The German pellet industry is very dynamic and the future position of Russian pellets on German markets is difficult to predict.

\subsubsection{Great Britain}

The UK has been a net exporter of wood pellets. In 2008, just over a third of the pellets (67 000 tons) manufactured in the UK was consumed within the country. Total exports in 2008 are estimated to be 93500 tons, of which the Republic of Ireland and Italy were the main consumers. In 2008, the main countries from which pellets were imported into the UK were Latvia and France with 22686 and 12939 tons, respectively. This was a change from 2007, when the majority of pellets was imported from Germany (40 000 tons) [73]. In 2010, pellet imports were about 0.55 million tons and exports were about 65000 tons. This increase is strongly driven by growing demand for industrial wood pellets for co-firing at power plants. The main suppliers of wood pellets to UK are Canada, U.S., Russia and South Africa, as well as EU member states, mainly Portugal, Germany and Estonia [5]. Although the UK is becoming a very 
large net importer of wood pellets, Russian pellets might have difficulties competing with pellets from the USA and Canada due to poor infrastructure.

\subsubsection{Belgium and the Netherlands}

Wood pellets markets in Belgium and the Netherlands are dominated by the utilization of pellets in large scale power plants [58]. After Sweden, Germany, and Italy, the Netherlands is the fourth largest wood pellet consumer in Europe, with a steadily increasing consumption that reached about 1.25 million tons in 2009 [4]. Production in the Netherlands is oriented to the domestic market and about $95 \%$ of the pellets are co-fired in large coal power plants [5,57,74]. Given the large demand and very limited domestic supply, more than $90 \%$ of all wood pellets consumed in 2009 were imported. Imports were mainly from Canada and the USA. Other, minor wood pellet streams are originated from Western Europe (mainly Portugal), the Baltics, South Africa, Australia, and North-West Russia [5].

Belgium has lower pellet production capacity that Germany and Austria. Wood pellet markets in the country are developing [57]. Pellet production in Belgium has experienced significant growth since 2005, increasing from a production capacity of 18000 tons up to 0.5 million tons in 2009. There are two main regions of wood pellet production in the country: Wallonia and Flanders, with 470000 and 30000 tons, respectively, in 2009. The growth in the production capacity from 2008 to 2009 was 50000 tons, which is below the amount for the last 4 years [5]. Currently, similar to the Netherlands, Belgium is a big consumer of wood pellets. Supported by government policies promoting both industrial and residential wood pellet use, the market can be expected to expand further in these countries. Due to the demand in the region, the potential of exports of Russian pellets to Belgium and the Netherlands seems promising.

\subsection{Results and discussion}

\subsection{Challenges}

The Russian pellet industry faces a number of other challenges in addition to the lack of significant domestic demand (see Section 3.2) and domestic standards (see Section 3.3), and an absence of reliable and clear statistical data (see Section 3.1).

One significant economic challenge is the incompatibility of the price of domestic pellets with the domestic oil price, which currently makes wood pellet production for the domestic market unviable. The high price for biomass, lack of a local pellet market and lack of subsidies for energy production from biomass make the industry unprofitable [26,74,75-77].

Despite the potential for development of biomass-related business in Russia, currently less than a half of available resources are used in biomass production. The total annual volume of wood waste in Russia is estimated to be 50-60 million tons [39]. The total annual growth of natural forest in Russia is approximately 1017 million $\mathrm{m}^{3}$ [78]. Underutilization of forest resources mostly occurs due to limited access to special equipment and modern technologies. Despite the vast available resources, there are examples of shortages of suitable raw material. For instance, "Vologdabioexport" from the Vologda region, one of the main pellet producers in Russia and one of the biggest pellet exporters from Russia to Europe, stopped production in 2010 due to a lack of raw material [29].

Russia has a substantial number of projects for pellet production, only a small share of which have been successfully implemented (see Fig. 6). The National Forestry Development Agency estimates that no more than $13 \%$ of pellet production capacity is utilized. Practically, this means 
that plants currently under construction may be doomed to chronic underutilization of capacity, and even bankruptcy [40]. The very low level of knowledge in business project management also hinders pellet industry development.

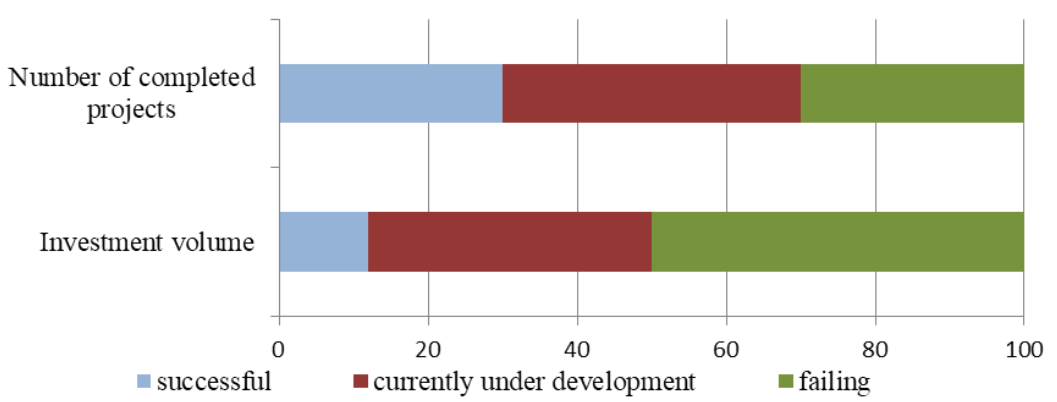

Fig. 6. Successfully implemented pellet production projects in Russia in \%, 2011 [40].

Due to the low bulk density and high moisture content of the raw material, pellet plants are usually located near sources of suitable raw material [79]. In Russia, most pellet production plants are located near sawmills. Thus, problems of sawmills affect pellet plants. If Russian sawmills face problems and are reducing production capacity, it leads to a decline also in pellet production.

A lack of good infrastructure has a detrimental effect on the Russian pellet industry. Russia does not generally have specialized port infrastructure for handling wood pellets. Companies whose facilities are located near docks ("Sawmill 25", "Biogran", and others) are a happy exception. However, in general, the difference in loading times for standardized shipments of industrial pellets is enormous compared with other countries. For instance, in Canada, the average loading time for standardized shipments of industrial pellets is a few hours, while in Russia, it is two to three days $[26,40]$.

The Russian government has official targets for renewable energy stimulation. For instance, in 2012, the Russian government adopted "The Comprehensive Program for Development of Biotechnology in the Russian Federation through 2020" $[21,80]$. However, there are no specific targets for wood pellets, and no interest from the Russian government in wood pellet development $[21,45,81]$, only the local programs for stimulation of pellet production in several regions.

\subsection{Development of Russian wood pellet industry}

It is possible to foresee major changes in Russian wood pellet production. Arkhangelsk Oblast could well take the leading position as regards pellet production in the near future, and Leningrad Oblast could become less important.

Arkhangelsk Oblast has local programs that stimulate wood pellet production and policy targets have been set to increase pellet production and biomass use. Several power plants have replaced natural gas with biomass. In August 2014, the first plant for the production of pellets from lignin will be put into operation by OAO "Bionet". "Rusforest", a company with headquarters in Sweden, launched a pellet production plant with 150000 tons per year near the Arkhangelsk wood sawmill "Arkhangelsk LDK No 3" in January 2014. Another competitive project in Arkhangelsk Oblast is "Sawmill 25", which plans to expand production two- to three-fold by 2014 [47]. In spite of the local-use policy, pellet exports will likely increase from the region.

Some other regions of Russia also seem promising. For instance, in Khanty-Mansi Autonomous Okrug, West Siberian region, grants are provided for each ton of wood briquettes and pellets that 
are sold (no matter whether within the region or for export). The company, German Pellets $\mathrm{GmbH}$ is considering building a 0.5 million tons per year pellet plant in the Nizhny Novgorod region, which in the center of the European part of the Russia with an estimated investment of 170-200 million euros [82]. Pellet production of 90000 tons is also planned near the new wood sawmill in Pskov, the Northwest of European Russia, where the acquisition of raw material is not problematic [47].

On the other hand, for comparison, development in Leningrad Oblast does not seem promising. The government does not support renewable energy at all and there is a lack of a systematic approach for wood pellet industry development. However, a new program that covers energy efficiency, regional support and stimulation of renewable use as well as stimulation of investments and policy support is under consideration. This program could start in 2015 but more realistically somewhat later [83]. The impact of the program on the pellet industry is unknown.

There is general consensus that the future of the Russian pellet industry is unclear. Increase in local wood pellet demand is uncertain and the wood pellet industry will continue to be exportoriented. EU demand alone cannot sustain the Russian wood pellet industry, although EU climate and energy targets (20-20-20) will continue to stimulate the industry. Despite the likely increase in EU wood pellet demand, the EU cannot afford, politically and economically, to depend completely on Russian wood pellets. The political situation in Russia, including the conflict in Ukraine [84], and the impact of sanctions on the EU-Russia relationship are also likely to affect the biofuel trade. Most industrial European consumers are seeking new players/countries from which to import pellets and existing partners from the EU are wary of long-term contracts with Russian suppliers. Thus, USA and Canada will likely continue to be in a leading position as regards wood pellet exports to Europe. In 2012-2013, exports from the United States nearly doubled from 1.6 million tons to 3.2 million tons, of which $98 \%$ was delivered to Europe $[14,71,85]$. It is unlikely that Russian trade volumes will be close to these two leading exporters of pellets in the foreseeable future.

It is possible, however, that Russian wood pellets could make their own niche in the Asian market. Exports of Russian pellets could increase, for example, to South Korea. It is predicted that the consumption of wood pellets by South Korea and Japan will be 3.8 million tons by 2015 and increase to 13.5 million tons by 2020 . South Korea has targets of decreasing GHG emissions and increasing power generation from renewable energy sources $[11,86]$. In the first 10 months of 2013, South Korea received 122500 tons of Russian pellets. The two main suppliers were from the Khabarovsk Krai region, the Russian Far East (OOO "SP Arkaim" and "Top Infra Ros"). Interestingly, the third largest supplier was ZAO "North-West Holding" in Leningrad Oblast, despite the long distance [87]. These recent wood pellet supplies from the Leningrad region to South Korea indicate that it is possible that Russian pellet exports as a whole may become more oriented to the Asian market and the supply of Russian pellets to Asia, mainly to South Korea, could be an important factor in global wood pellet trade.

\section{Conclusions and recommendations}

Pellet production in Russia is a relatively new industry compared to most European countries and the United States. The pellet business is growing, and large companies are driving the increased pellet production, as can be seen from the dynamics of pellet export and production. 
No ports specialize in pellet handling and Russia suffers from a lack of good infrastructure that can provide sustainable wood pellet transportation.

In the past 3-4 years, there have not been significant changes in world pellet markets. The USA and Canada are the leading volume producers of pellets for export, with Russia lagging far behind. The current study demonstrates that there are a lot of constraints on the Russian wood pellet industry. The main European consumers of Russian pellets are Denmark and Sweden. The lead consumers of pellets in Europe are Sweden, Germany, Italy, and the Netherlands, where, excluding Sweden, the share of Russian pellets is negligible. In most of these countries, Russian pellets cannot compete with pellets from the USA and Canada.

New players on the Russian pellet market face restricted opportunities. For instance, they lack guaranteed access to raw materials, have problems producing large volumes of high quality pellets, and are unable to negotiate reduced transportation costs for regular shipments of large quantities. Consequently, a few large companies dominate wood pellet production in Russia and account for almost all Russian wood pellet exports.

On the domestic market, the number of pellet producers will probably decline due to the exit of small market players. In addition to the challenges discussed in this paper, Russian business culture factors, bureaucracy, 6-month winters, language difficulties, and even personal safety together create seemingly insurmountable barriers for the development of a large-scale export Russian bioenergy business [88].

In principle, the Russian wood pellet industry is export-oriented and exhibits great export potential, as current EU policy aims to stimulate greater use of biofuel, including pellets. Growing interest in the European Union for wood pellets will continue to be a major incentive for Russia to increase the production of wood pellets, and wood pellet demand from Scandinavia will continue to be attractive for the Russian wood pellet industry. However, in order to make full use of these opportunities, Russia will need to make large investments to upgrade facilities and expand its production capacity.

In a long term perspective, it is possible to see big changes on the wood pellet market due to the development of renewable energy in Asia and other parts of the world. The possible establishment of new woody plantations for energy in Ukraine, where the potential extra supply of woody biomass is estimated to be about 135 million tons [89], could put further pressure on Russian wood pellet exports to Europe (see Table 5). If Russia does not address the problems mentioned in this paper, export of Russian wood pellets to the EU can be expected to remain constant or even decline.

The purpose of the current study was to present a general overview of the Russian pellet industry, showing the current complex situation the industry is operating in. The study is of value in that it provides a foundation for the creation of possible future scenarios.

Many questions remain open for further investigation. The lack of accurate, reliable data on which to base policy decision-making is clearly a topic that needs to be addressed. Further work needs to be done to establish the interaction of the many factors affecting wood pellet logistics and price. Which factors influence the final price of pellets, how could the logistics be improved, what exactly needs to be done for better development of international trade in Russian pellets are all pertinent issues for study. In addition, the impact of government policies on the wood pellet industry, and a possible increase in domestic pellet consumption and its impact on export and production could also be issues for further research. 


\section{Acknowledgements}

Part of this work was funded by the Fortum Foundation, Finland, whose support is gratefully acknowledged. We would like to thank Peter Jones (LUT) and Anton Orlov (SPbFTU) for valuable comments. 


\section{References}

[1] Dahlquist E. Technologies for converting biomass to useful energy-combustion, gasification, pyrolysis, torrefaction and fermentation. 2013. p. 345-55.

[2] Pellet fuel institute. What are pellets? 2011. http://pelletheat.org/pellets/what-are-pellets/ [accessed 25 10.13].

[3] BioEnergy Inc. Advantages of Wood Pellets; 2010. http://www.bioenergyinc.ca/WoodPelletAdvantages/ [accessed 25 10.13].

[4] Indeck energy. Wood pellets. The Benefits of Wood Pellets; 2013. http://www.indeckpellets.com/why.php [accessed 05.11.13].

[5] Cocchi M, Nikolaisen L, Junginger M, Goh CS, Heinimö J, Bradley D, et al. Global Wood Pellet Industry Market and Trade study. IEA Bioenergy Task 2011;40. http://www.bioenergytrade.org/downloads/t40-global-wood-pellet-market-study_final.pdf [accessed 08.11.13].

[6] Kuparinen K, Heinimö J, Vakkilainen E. World's largest biofuel and pellet plantsGeographic distribution, capacity share, and feedstock supply. Biofuels, Bioproducts and Biorefining 2014;8:747-54.

[7] Trømborg E, Ranta T, Schweinle J, Solberg B, Skjevrak G, Tiffany DG. Economic sustainability for wood pellets production-A comparative study between Finland, Germany, Norway, Sweden and the US. Biomass and Bioenergy 2013;57:68-77.

[8] Proskurina S, Vakkilainen E, Heinimö J, Mikkilä M. The Russian Wood Pellet Business: Exports to the Nordic Area. In: 22nd European Biomass Conference and Exhibition. Hamburg, Germany 2014.

[9] Peksa-Blanchard M, Dolzan P, Grassi A, Heinimö J, Junginger M, Ranta T, et al. Global wood pellets markets and industry: Policy drivers, market status and raw material potential. $\begin{array}{lll}\text { IEA Bioenergy 2007;40. } & \text { Task }\end{array}$ http://www.bioenergytrade.org/downloads/ieatask40pelletandrawmaterialstudynov2007final .pdf [accessed 18.12.13].

[10] Kummamuru VB, Lang A, Calderon C, Bradley D, Gauthier G, Kopetz H, et al. WBA Global Bioenergy Statistics 2014. World Bioenergy Association; 2014. http://www.worldbioenergy.org/userfiles/140526\%20-\%20WBA\%20GBS\%202014.pdf [accessed 25 .12.13].

[11] Bradley D, Hektor B, Wild M, Deutmeyer M, Paul Schouwenberg P, Hess R, et. al. Low Cost, Long Distance Biomass Supply Chains. IEA Bioenergy Task 2013;40. http://www.svebio.se/sites/default/files/t40-low-cost-long-distance-biomass-supplychains.pdf [accessed 08.02.14].

[12] Lamers P, Marchal D, Heinimö J, Steierer F. Global wood biomass trade for energy. In: Junginger M, Goh CS, Faaij A, editors. International bioenergy trade, New York: EPublishing Inc; 2014, p. 41-3.

[13] Heinimö J, Ojanen V, Kässi T. Views on the international market for energy biomass in 2020: Results from a scenario study. International Journal of Energy Sector Management 2008;2:547-69.

[14] Junginger M, Bolkesjø T, Bradley D, Dolzan P, Faaij APC, Heinimö J, et al. Developments in international bioenergy trade. Biomass and Bioenergy 2008;32:717-29.

[15] Moiseyev A, Solberg B, Maarit A, Kallio L. The impact of subsidies and carbon pricing on the wood biomass use for energy in the EU. Energy 2014;76:161-67.

[16] The magazine of corporate real estate strategy \& area economic development. More pellets, please!; 2013. http://www.siteselection.com/issues/2013/jul/world-reports.cfm?s=ra [accessed 08.02.14].

[17] Wood markets. Wood pellet market outlook. Monthly international report, volume 18, No.1; 2013. $\quad$ http://www.woodmarkets.com/wp-content/uploads/2014/02/WMM-Feb13.pdf [accessed 08.02.14]. 
[18] Hoefnagels R, Resch G, Junginger M, Faaij APC. International and domestic uses of solid biofuels under different renewable energy support scenarios in the European Union. Applied Energy 2014;15:139-57.

[19] Goh CS, Junginger M, Cocchi M, Marchal D, Thrän D, Hennig C, et al. Wood pellet market and trade: A global perspective. Biofuels, Bioproducts and Biorefining 2013;7:24-42.

[20] What wood. Russian pellets on the global market; 2013. http://whatwood.ru/english/russianpellets-on-the-global-market [accessed 18.03.14].

[21] TheCropSite. USDA GAIN: Russian Federation Biofuels Annual 2013; 2013. http://www.thecropsite.com/reports/?id=2403 [accessed 25.04.14].

[22] ЭкспертOnline. Основные производители пеллет в России. (ExpertOnline. The main producers of wood pellets in Russia); 2012 [In Russian]. http://expert.ru/ratings/osnovnyie-proizvoditeli-pellet-v-rossii/ [accessed 05.02.14].

[23] Aleksandrova N. Characteristics of Creation of the Wood Pellets Market in Russia. Journal of Siberian Federal University Humanities \& Social Sciences 2008;1:443-54.

[24] Heinimö J, Lamers P, Ranta T. International Trade of Energy Biomass-An overview of the past development. In: 21st European Biomass Conference and Exhibition. Copenhagen, Denmark 2013.

[25] Heinimö J, Junginger M. Production and trading of biomass for energy-An overview of the global status. Biomass and Bioenergy 2009;33:1310-20.

[26] Orlov А. Экономические проблемы пеллетного производства. (Economic problems of pellets production). Saint Petersburg State Forest Technical University ; 2013 [In Russian]. http://spbftu.ru/UserFiles/Image/izvesti/20-205.pdf [accessed 05.04.14].

[27] Selkimäki M, Mola-Yudego B, Rösera D, Prinz R, Sikanen L. Present and future trends in pellet markets, raw materials, and supply logistics in Sweden and Finland. Renewable and Sustainable Energy Reviews 2010;14:3068-75.

[28] Rakitova O, Kholodkov V. Final Report of The Pellet market and wood resources in the North-West of Russian. Baltic 21 Lighthouse project The Baltic Sea Bioenergy Promotion Project. 2009.

[29] Information and Analytical Agency "Infobio". The development of the pellet production and trade in Russia production and trade in Russia; 2012. http://www.infobio.ru/sites/default/files/Russian_pellets_Rakitova2012.pdf $\quad$ [accessed 25.01.14].

[30] JSC Vyborgskaya Cellulose. Company's official webpage; 2011. http://vybcell.ru/en.html [accessed 25.01.14].

[31] Information and Analytical Agency "Infobio". Росприроднадзор выиграл иск против ООО “Выборгская лесопромышленная корпорация". (RosPotrebNadzor has won a lawsuit against the LLC "Vyborg Timber Corporation"); 2013 [In Russian]. http://www.infobio.ru/news/2366.html [accessed 25.01.14].

[32] Ultralam, Taleon Terra Product. Company's official webpage; 2014. http://www.ultralam.com/company.php [accessed 05.02.14].

[33] Information and Analytical Agency "Infobio". ИАА «ИНФОБИО» составило рейтинг 10 крупнейших производителей-экспортеров древесных топливных гранул. (IAA "INFOBIO" find out the top 10 largest manufacturers, exporters of wood pellets); 2014 [In Russian]. http://www.biointernational.ru/news/2663.html [accessed 15.01.14].

[34] BIOWATT. Сценарии увеличения производства древесного топлива в Архангельской области. (Scenarios of increasing the production of wood fuel in the Arkhangelsk region); 2013 [In Russian]. http://www.biowatt.com.ua/analitika/stsenarii-uvelicheniyaproizvodstva-drevesnogo-topliva-v-arhangelskoj-oblasti/ [accessed 25.04.14].

[35] АРРМ. Сценарий умеренного развития ЛПК региона предусматривает увеличение объема производства древесного топлива к 2020 г. до 280 тыс. тонн. (APPM. Scenario of temperate forestry development in the region plans increase the volume of wood fuel production in 2020 to 280000 tons); 2013 [In Russian]. http://www.appm.ru/news/1068/ 
[accessed 05.04.14].

[36] GreenEvolution. В Архангельской области приступили к строительству завода по производству пеллет. (Construction of a plant for the pellets production is started in the Arkhangelsk region); 2013 [In Russian]. http://greenevolution.ru/2013/09/27/varxangelskoj-oblasti-pristupili-k-stroitelstvu-zavoda-po-proizvodstvu-pellet/] [accessed 08.05.14].

[37] Rosstat. Russian Federal Statistics Service. Moskow. Russia. http://www.gks.ru/wps/wcm/connect/rosstat_main/rosstat/en/main/ [accessed 25.06.14].

[38] Duca D, Riva G, Pedretti EF, Toscano G. Wood pellet quality with respect to EN 14961-2 standard and certifications. Fuel 2014;135:9-14.

[39] USDA Foreign Agricultural Service. EU Biofuels Annual 2013. Gain report No.NL3034; 2013.

http://gain.fas.usda.gov/Recent\%20GAIN\%20Publications/Biofuels\%20Annual_The\%20Ha gue_EU-27_8-13-2013.pdf [accessed 08.02.14].

[40] ЭкспертOnline. Когда опилки дороже нефти. (ExpertOnline. When sawdust is more expensive than oil); 2012 [In Russian]. http://expert.ru/expert/2012/25/kogda-opilkidorozhe-nefti/ [accessed 05.02.14].

[41] LesOnline. Пеллетное производство России 2014 г. (The wood pellets production in Russia 2014); 2014 [In Russian]. http://www.lesonline.ru/n/3E497 [accessed 08.03.15].

[42] Eurostat. "EU trade since 1995 by CN8"; 2009. http://epp.eurostat.ec.europa.eu [accessed 18.02.14].

[43] USDA Foreign Agricultural Service. Agricultiral Biotechnology Annual 2014. Gain report No.RS 1444; 2014.

http://gain.fas.usda.gov/Recent\%20GAIN\%20Publications/Agricultural\%20Biotechnology \%20Annual_Moscow_Russian\%20Federation_7-11-2014.pdf [accessed 10.03.15].

[44] LesOnline. Топливная древесина и пеллеты-2013 г. Цифры и факты. (Firewood and pellets-2013 Facts and Figures); 2014 [In Russian]. http://www.lesonline.ru/n/3B3E3 [accessed 08.05.14].

[45] personal information 19.06.2014 from a large Russian pellet manufacturer

[46] Rakitova O, Ovsyanko A, Sikkema R, Junginger M. Wood Pellets Production and Trade in Russia, Belarus \& Ukraine. Pellets@ las; 2009. www.pelletsatlas.info [accessed 25.02.14].

[47] García-Maraver A, Popov V, Zamorano M. A review of European standards for pellet quality. Renewable Energy 2011;36:3537-40.

[48] The Bioenergy international. Древесные топливныые гранулы в России: итоги 2013 г. (Wood pellets in Russia: Results of 2013); 2014. No.1 (30). In: Information and Analytical Agency "Infobio" [In Russian].

[49] Azeus Biopellet Machines. DIN plus pellets or EN plus pellets. http://www.biopelletmachine.com/biopellets-making-guidance/wood-pellet-certificationstandard.html [accessed 18.11.14].

[50] European Pellet Council. Handbook for the Certification of Wood Pellets for Heating Purposes. Version 2.0. Brussels: AEBIOM-European Biomass Association; 2013. http://www.enplus-pellets.eu/ [accessed 06.05.14].

[51] Biomass Energy Center. CEN/TC 335 Biomass standards; 2008. http://www.biomassenergycentre.org.uk/portal/page?_pageid $=77,19836 \&$ dad=portal\&_sch ema=PORTAL [accessed 06.05.14].

[52] Biomass Magazine. Forest Certification: Opportunity and Challenge for the Wood Pellet Industry; 2012. http://biomassmagazine.com/articles/6258/forest-certification-opportunityand-challenge-for-the-wood-pellet-industry [accessed 16.03.15].

[53] Sostav.ru. В России основная часть пеллет уходит на экспорт, хотя могла бы использоваться для собственных нужд. (In Russia, the biggest part of pellets is exported, although it could be used for their own needs); 2014 [In Russian]. 
http://www.sostav.ru/blogs/84464/12736/ [accessed 10.01.14].

[54] Wood-pellets.com. 2013-12-25-за 10 месяцев 2013 года в экспортно-импортной внешнеэкономической деятельности выделилось пять лидеров по объемам экспорта топливных гранул в Европу. (Five leaders are identified in exports of wood pellets to Europe for 10 months in 2013); 2014 [In Russian]. http://www.wood-pellets.com/cgibin/cms/index.cgi?ext=news\&lang=1\&nid=2894\&sub=show_news [accessed 05.01.14].

[55] Eurostat. Forestry statistics overview; 2013.

http://epp.eurostat.ec.europa.eu/statistics_explained/index.php/Forestry_statistics_overview [accessed 16.04.14].

[56] Lamers P, Junginger M, Hamelinck C, Faaij APC. Developments in international solid biofuel trade-An analysis of volumes, policies, and market factors. Renewable and Sustainable Energy Reviews 2012;16:3176-99.

[57] Mola-Yudego B, Selkimäki M, González-Olabarria JR. Spatial analysis of the wood pellet production for energy in Europe. Renewable Energy 2014;63:76-83.

[58] Sikkema R, Steiner M, Junginger M, Hiegl W, Hansen MT, Faaij, A. The European wood pellet markets: current status and prospects for 2020. Biofuels, Bioproducts and Biorefining 2011;5:250-78.

[59] Beurskens LWM, Hekkenberg M. Renewable Energy Projections as Published in the National Renewable Energy Action Plans of the European Member States. European Environment Agency; 2011. file:///C:/Users/user/Downloads/NREAP_Final.pdf [accessed 08.03.14].

[60] Karkania V, Fanara E, Zabaniotou A. Review of sustainable biomass pellets production-A study for agricultural residues pellets' market in Greece. Renewable and Sustainable Energy Reviews 2012;16:1426-36.

[61] Olsson O, Hillring B, Vinterbäck J. European wood pellet market integration-A study of the residential sector. Biomass and Bioenergy 2011;35:153-60.

[62] Encyclopedia of safety. Denmark ahead of Sweden Procurement Russian pellets; 2011. http://survincity.com/2011/11/denmark-ahead-of-sweden-procurement-russian/] [accessed 05.04.14].

[63] Heinimö J, Alakangas E. Market of biomass fuels in Finland-An overview 2009 IEA Bioenergy Task 40 and EUBIONET III-Country report of Finland 2011. Finland, Lappeenranta: Lappeenranta University of Technology; 2011. http://www.bioenergytrade.org/downloads/iea-task-40-country-report-2011-finland.pdf [accessed 08.03.14].

[64] Hämäläinen A, Panapanaan V, Mikkilä M, Linnanen L, Heinimö J. Sustainability criteria for biomass-Views of Finnish stakeholders. International Journal of Energy Sector Management 2011;5:307-26.

[65] Sikkema R, Faaij APC, Ranta T, Heinimö J, Gerasimov YY, Karjalainen T et al. Mobilization of biomass for energy from boreal forests in Finland \& Russia under present sustainable forest management certification and new sustainability requirements for solid biofuels. Biomass and Bioenergy 2014;71:23-36.

[66] Finnish Pellet Energy Association. Lausunto ilmasto- ja energiastrategiaan 19.5.2009. (Pronouncement on the Finnish climate and energy strategy); 2009 [In Finnish]. http://www.pellettienergia.fi [accessed 05.01.14].

[67] Selkimäki M, Prinz R, Mola-Yudego B, Röser D. Pellet market, raw materials, handling and logistics in Northern Periphery. Metla.fi. Working Papers of the Finnish Forest Research Institute; 2011. http://www.metla.fi/julkaisut/workingpapers/2010/mwp157.pdf [accessed 08.03.14].

[68] EC. Finland's national action plan for promoting energy from renewable sources pursuant to Directive 2009/28/EC. European Commission, NREAP; 2010. http://ec.europa.eu/energy/renewables/action_plan_en.htm [accessed 15.03.14].

[69] Thrän D, Hennig C, Thiffault E, Heinimö J, Andrade O. Development of bioenergy trade in 
four different settings - The role of potential and policies. In: Junginger M, Goh CS, Faaij A, editors. International bioenergy trade, New York: E-Publishing Inc; 2014, p. 65-101.

[70] Heinimö J. Methodological aspects on international biofuels trade: International streams and trade of solid and liquid biofuels in Finland. Biomass and Bioenergy 2008;32:702-16.

[71] Statistics Finland. Statistics Finland's PX-Web databases. http://pxweb2.stat.fi/Dialog/varval.asp?ma=030_ehk_tau_103_en\&path=../database/StatFin/ ene/ehk/\&lang=1\&multilang=en [accessed 18.11.14].

[72] Kristöfel C, Strasser C, Morawetz UB, Schmidt J, Schmid E. Analysis of woody biomass commodity price volatility in Austria. Biomass and Bioenergy 2014;65:112-24.

[73] Haye S. Pellet market country report UK. Pellets@las;2009. www.pelletsatlas.info [08.07.2014].

[74] Vivarelli F. Development and promotion of a transparent European pellets market creation of a European real-time Pellets Atlas. Pellet market country report Portugal. ETA

Renewable Energies; 2009. www.pelletsatlas.info [accessed 15.03.14].

[75] Martinot E. Renewable energy in Russia: markets, development and technology transfer. Renewable and Sustainable Energy Reviews 1999;3:49-75.

[76] Ulybina O, Fennell S. Forest certification in Russia: Challenges of institutional development. Ecological Economics 2013;95:178-87.

[77] Zhang H, Lianshui L, Cao J, Zhao M, Wu O. Comparison of renewable energy policy evolution among the BRICs. Renewable and Sustainable Energy Reviews 2011;15:4904-09.

[78] FAO. The Russian Federation forest sector Outlook Study to 2030. Rome, Italy, Food and agriculture organization of the United Nations; 2012. http://www.fao.org/docrep/016/i3020e/i3020e00.pdf [accessed 15.03.14].

[79] Mobinia M, Meyerb JC, Trippeb F, Sowlatia T, Fröhlingb M, Schultmannb F. Assessing the integration of torrefaction into wood pellet production. Journal of Cleaner Production 2014;78:216-225.

[80] USDA Foreign agricultural Services. Russian Federation. Program on Development of Biotechnology in Russia through 2020. GAIN Report number: RS1239 Date: 6/8/2012.

[81] Леспроминформ. Перспективы мирового рынка пеллет. (Lesprominform. Global wood pellets markets perspective); 2010 [In Russian] http://lesprominform.ru/jarchive/articles/itemshow/1206 [08.07.2014].

[82] Information and Analytical Agency "Infobio". German Pellets GmbH запустит завод мощностью 500000 т/год пеллет в Нижегородской области. (German Pellets GmbH will launch a plant with capacity of 500000 ton/year of pellets in the Nizhny Novgorod region); 2014 [In Russian]. http://www.infobio.ru/news/2639.html [accessed 15.03.14].

[83] Smirnova L. Развитие биоэнергетики в Ленинградской области. (Bioenergy development in Leningrad Oblast). In: Conference by Information and Analytical Agency "Infobio":"Энергия из биомассы:котельные и ТЭЦ на биотопливе, производство пеллет, брикетов, биогаза в России". ("Energy from biomass: heat and power production from biofuel; production of pellets, briquettes and biogas in Russia") [In Russian]. St.Petersburg, Russia 2014.

[84] Goldthau A, Boersma T. The 2014 Ukraine-Russia crisis: Implications for energy markets and scholarship. Energy Research \& Social Science 2014;3:13-15.

[85] BE Sustainable. Bioenergy and bioeconomy news around the world; 2014. http://issuu.com/besustainablemagazine/docs/be-sustainable_june_2014 [accessed 18.03.14].

[86] $\mathrm{Ku}$ SJ, Yoo SH. Willingness to pay for renewable energy investment in Korea: A choice experiment study. Renewable and Sustainable Energy Reviews 2010;14:2196-201.

[87] Information and Analytical Agency "Infobio". ИАА «ИНФОБИО», за два первых осенних месяца Южная Корея импортировала из россии такое же количество пеллет, как за полгода (IAA "INFOBIO" for the first two months of autumn South Korea imported from Russia the same amount of pellets as six months of privies year); 2013 [In Russian]. http://www.infobio.ru/news/2627.html [accessed 18.04.14]. 
[88] Deutmeyer M, Bradley D, Hektor B, Hess JR, Tumuluru LS, Nikolaisen L, et al. Possible effect of torrefaction on biomass trade. IEA Task 2012;40. http://www.bioenergytrade.org/downloads/t40-torrefaction-2012.pdf [accessed 25.04.14].

[89] de Wit M, Faaija A. European biomass resource potential and costs. Biomass and Bioenergy 2010;34:188-202. 